\title{
EXPLORING RELATIONSHIP AMONG E-LEARNING PLATFORMS, TECHNICAL SYSTEM QUALITY AND PERCEIVED STUDENTS' SATISFACTION ON HIGHER EDUCATIONS' SYSTEM FOR E-LEARNING
}

\author{
Leonnard \\ Program Studi Manajemen Bisnis, Sekolah Tinggi Manajemen IPMI \\ Address : Jl. Rawajati Timur I/1, Kalibata, Jakarta Selatan, Indonesia 12750 \\ *E-mail : leonnardong1@gmail.com
}

\begin{abstract}
Currently, most Indonesian universities have adopted an online academic management information system (AMIS) to provide academic and administrative service activities. This study aims to explore the relationship between the e-learning platforms and the technical system quality, and the perceived satisfaction of students. Data were collected using questionnaires distributed to 286 students of a university. The questionnaire showed that there is a difference in the e-learning tools, techniques, or platforms used by the students. The results of the chi-square test show that there is no significant relationship between e-learning platform and technical system quality and also perceived satisfaction of the students. That shows the platform choices do not affect students' perception of quality and satisfaction. However, technical system quality is significantly related to perceived student satisfaction. Therefore, the e-learning quality should be improved in line with the innovation of a learning system during the pandemic, so that students' satisfaction in the learning involvement increase.
\end{abstract}

Keywords: e-learning platforms, technical system quality, perceived students' satisfaction JEL Classification: $\mathrm{O} 33, \mathrm{O} 35$

Article History:

Received: December 30, 2020; Revised: March 22, 2021; Accepted : March 27, 2021; Available Online : April 26 , 2021

DOI : $10.20473 / \mathrm{imtt} . v 14 \mathrm{il} .24183$

\section{INTRODUCTION}

Today, all over the world have experienced Covid-19 pandemic conditions. Until May 2020, South Africa with 9,400 cases, India with 62,000 cases, Australia with 6,900 cases. They have shown significant changes in various aspects both institutionally, professionally, and for the community, especially related to education (Verma et al., 2020). The implication of the Covid-19 pandemic is the reduction in face-to-face interactions also physical distancing policies include those in the world of education. That, in turn, makes universities have to use a distance learning system.

Distance-learning is one of used the ICT innovation approach, usually better known as elearning. E-learning provides educational service through an innovative approach of electronic information that will strengthen the knowledge, skills, and other outcomes of learners (Fazlollahtabar and Muhammadzadeh, 2012). Several benefits of e-learning, such as cost savings associated with investing in learning infrastructure substantially, university 
becoming more digitalized, and contributing to the digital form of the learning process where learning process can be done in a simple and fast way wherever and whenever with internet-enabled technologies (Pham et al., 2019).

Besides, with e-learning, the university will be more integrated with the global education environment, without state borders. The students will also feel the ease of e-learning, including students who are also workers, so students can control the pace and rhythm of learning because they do not need to be physically present on campus. Most universities in Indonesia have adopted an online academic management information system (AMIS) to provide academic and administrative service activities, from student registration, payments, filling out the Study Plan Card, scheduling information, rooms, lecturers, grades, lecturer evaluations and learning, registration for Field Work Practices and access to an online library.

The development of e-learning in Indonesia has also entered a strategic phase in the current Covid-19 pandemic. Various platforms, applications, or techniques are introduced and used by campus or school institutions, as well as instructors, ranging from simple to sophisticated versions, for example, WhatsApp groups, Google Hangouts Meet, Google Classroom, Zoom Meetings, portals from universities, or even various combinations of these applications. Each has advantages and disadvantages in terms of quality and satisfaction perceptions.

In Indonesia, there is still a lack of research on perceived quality and satisfaction for distance learning or e-learning. Several studies in developed countries, for example, America (Shaik, Lowe and Pinegar, 2006; Peltier, Schibrowsky and Drago, 2007), Spain (Martinez-Arguelles, Callejo and Farrero, 2013; Martinez-Arguelles and Batalla-Busquets, 2008), as well as in Asian countries (Lin, 2007; Wang, Wang and Shee, 2007; Masrom, Zainon and Rahiman, 2008; Ali, Hossain and Ahmed, 2018; Pham et al., 2019) have suggested several attributes/factors that affect the quality of e-learning, but for Indonesia, which is currently experiencing a Covid-19, not many studies have been found. The technical quality of the platform is usually the main factor in the selection of the intended application. This consideration may also impact student satisfaction towards its learning process. Thus, the study aims to explore the relationship between e-learning platforms, technical system quality, and perceived satisfaction of the students.

\section{LITERATURE REVIEW AND HYPOTHESES}

\section{Platforms/Applications for E-Learning}

Online learning or e-learning is related to the ability to use a computer or network technology for learning purposes from anywhere, anytime, in any rhythm, with any means (Cojocariu V.-M., Lazar I., Nedeff V., 2014). Furthermore, Fazlollahtabar and 


\section{Leonnard}

Muhammadzadeh, (2012) stated that e-learning is an innovative approach of information electronic forms that will strengthen the knowledge, skills, and other outcomes of learners. (Valverde-Berrocoso et al., 2020) reviewed in three specialized journals in Educational Technology and resulted in the keywords that most frequently used in e-learning studies, namely MOOC, Higher Education, Teaching-Learning Strategies, and Interactive Learning Environments. Massive Open Online Course (MOOC) is the most used e-learning modality. The students who participate in MOOCs need improvement in cognitive knowledge as well as certification and the improvement of their professional skills.

Meanwhile, various platforms, applications, or techniques are used to support the e-learning process. As mentioned before, it can be google products (Google Hangouts Meet, Google Classroom, Zoom Meetings), WhatsApp groups, zoom meeting, education cloud, or portals from universities. Here is a short explanation of those applications/platforms.

Google is a multinational company headquartered in the United States that provides Internet-related services and products, including online advertising technology, search engines, cloud computing, software, and hardware. Some applications/platforms from Google that are well known in Indonesia and are used in e-learning include Google Meet, Google Hangout Meet, and Google Classroom. Google Meet is a video conferencing application, previously called Hangouts Meet, and rebranded to Google Meet (Google, 2020). Then in May 2020, Google announced it to be a free version. Meanwhile, Google Classroom is a feature of the Google application that works closely with teachers throughout the country to create Classroom (Google, 2020a). Google Classroom can help teachers manage assignments. Besides, in one application, instructors can also create several classes, give assignments, grades, feedback, and see everything.

Another simple application that can be used for an education process in Indonesia is WhatsApp. WhatsApp is a texting application that uses an internet connection from a telephone to send messages (WhatsApp, 2020). By using an internal connection, users can prevent SMS fees. WhatsApp also provides a group feature that allows its users to keep in touch with groups of people, up to 256 people. With group chats, participants can share messages, photos, and videos.

Meanwhile, an application of video conferencing has started to boom in Indonesia since the Covid-19 pandemic. The zoom application is a video conferencing platform that can provide real-time messaging and content sharing (Zoom, 2020). Zoom can be used for 1000 participants, and even 49 videos on-screen shared simultaneously to create a more interactive meeting. 
There is also a more sophisticated application used for e-learning in Indonesia. Some education institution has their portals or some use built-in applications already, such as the education cloud. Education Cloud is an application that combines various customer relationship management (CRM) services in the higher education industry (Salesforce, 2020). This application provides services ranging from registration information, recruitment and admission, teaching and learning process until graduation, and engaged alumni. Education cloud enables the integration of data that was siloed previously into an integrated educational journey. The e-learning portal from the university can also provide these services. The service can be started from the process of admission, learning process, until the graduation process.

Different countries have different preferences towards the platform options. In Georgia, for example, online portal, TV School and Microsoft Teams for public schools and the alternatives like Zoom, Slack and Google Meet, EduPage platform use for online education and live communication (Basilaia and Kvavadze, 2020). Meanwhile, in India, they develop Byju's, Adda247, Alolearning, AptusLearn, Asmakam, Board Infinity, ClassPlus, CyberVie, Egnify, Embibe, ExtraaEdge, iStar, Jungroo Learning, GlobalGyan, Lido Learning, Pesto, Vedantu, Edubrisk, Zoom Classroom, Zoom Business, Toppr, Unacademy, Coursera, Kahoot, Seesaw, Khan Academy, e-pathshala, GurUQ, SWAYAM portal that initiated by the government, and also use Google Hangouts, Skype, Adobe Connect, Microsoft teams (Dhawan, 2020). Dhawan (2020) also found that zoom application is the most preferable in India.

Those various platforms/applications usage and preferences may depend on several factors. The factors that affect the choice of a particular technology include security features, availability and condition of laboratories, internet speed, internet access, and digital literacy levels of the users (Dhawan, 2020). The technical quality of the platform is usually the main factor in the selection of the intended application. Virtual teaching environments can be successful in case of having an appropriate technical environment (Basilaia and Kvavadze, 2020). Therefore, a quick transition towards an online form of education needs to address to gain more benefit from e-learning (Basilaia and Kvavadze, 2020), including the satisfaction of the users of inclusive education even at the time of crisis.

\section{Technical System Quality}

Several methods have been developed to measure e-service quality. In the beginning, the method was purposed to measure the e-service quality of online shopping sites. Some popular methods are WebQual (Barnes and Vidgen, 2002) which is used to measure e-service quality in e-commerce by employing five indicators: design, usability, trust, information, and empathy. Another method is SITEQUAL (Yoo and Donthu, 2001) which consists of four 


\section{Leonnard}

indicators: ease of use, aesthetic design, processing speed, and security. However, the method provides a disadvantage. Those respondents can do the assessments without completing purchases. Thereafter, Wolfinbarger and Gilly, (2003) developed eTailQ consisted of four indicators: website design, fulfillment or reliability, security, and customer service. However, both website design and customer service are considered to be less consistent and distinct. To improve and complete the shortcomings in the previous methods, (Zeithaml, Parasuraman and Malhotra, 2002)) suggested five indicators of e-SERVQUAL consisted of content and information availability, ease of use, privacy, graphic style, and reliability. Later in 2005, these indicators were refined into a new method called E-S-QUAL with four indicators of efficiency, fulfillment, system availability, and privacy (Parasuraman, Zeithaml and Malhotra, 2005). It is developed to evaluate the e-service quality of online shopping sites, not on other forms of internet sites such as portals, free download sites, job sites, or newspaper sites aimed at special purposes such as advertising other than online shopping (Parasuraman, Zeithaml and Malhotra, 2005).

Some other methods such as NetQual (Bressolles and Nantel, 2008), ESELFQUAL (Ding, Hu and Sheng, 2011)were developed after that period. However, most of the methods aim to evaluate the e-service quality of online shopping sites. Moreover, there were E-GOVSQUALRISK (Rotchanakitumnuai, 2008), E-GOV-SQUAL (Kaisara and Pather, 2011), PUBLIC VALUE OF E-GOVERNMENT (Karunasena and Deng, 2012) to evaluate e-service quality of public sectors, and LibQUAL for libraries (Zhang and Bi, 2017). Lee, Choi and Jo, (2009) used the end-user computing satisfaction model consisting of user ability, design, playfulness, and support services available to evaluate student satisfaction of the university's portal. Chen, (2011) and Tella and Bashorun, (2012) used the dimensions of ease of use, information quality, and system quality. Besides, Shaltoni et al., (2015) used dimensions of information quality, system quality, and user ability to evaluate the perceived service quality of university's portals in developing countries. Most of the dimensions used in the literature are developed based on E-SERVQUAL dimensions. In this study, we used the latest version of e-SERVQUAL, e-core service quality scale (E-S-QUAL), as a result of the reduction of previously developed dimensions. E-S-QUAL consists of efficiency, fulfillment, system availability, and privacy. Efficiency is the ease and speed of accessing the information on the sites. Fulfillment is the ability of the sites to provide the information required. System availability is the ability of the system to work according to its functions and privacy is the level of trust of the sites in maintaining consumer information confidentiality (Parasuraman, Zeithaml and Malhotra, 2005). 
Perceived quality is the outcomes of the products and services evaluations conducted comprehensively by consumers (Zeithaml, 1988). Given that educational institutions are institutions that provide services, usually, a service quality approach is used to assess the quality of learning (Leonnard, 2018a). The quality of service in higher education is believed to have a significant relationship to loyalty (Leonnard et al., 2015) and to trust (Leonnard and Susanti, 2019). To evaluate service quality, there are 2 indicators including technical quality and functional quality (Grönroos, 1984). Technical quality is defined as the physical quality while functional quality is the quality of service delivery (Rust and Oliver, 1993).

Based on the discussion in this study, e-learning is a service provided by educational institutions, and its quality also needs to be evaluated. Some research shows the approaches or attributes used to evaluate e-learning service quality. Most of the research focused on issues other than technical factors, or functional quality and focused on specific region/country only, for example, Lin, (2007) in Taiwan, Martinez-Arguelles, Callejo and Farrero, (2013) and Martinez-Arguelles and Batalla-Busquets, (2008) in Spain, Pham et al., (2019) in Vietnam, Shaik, Lowe and Pinegar, (2006) in the US, Wang, Wang and Shee, (2007) in Taiwan. On the other hand, only a few research use a technical approach for assessing the quality of e-learning, such as Ali, Hossain and Ahmed, (2018) in Bangladesh, Masrom, Zainon and Rahiman, (2008) in Malaysia, and Peltier, Schibrowsky and Drago, (2007) in the US. Although some other researchers also partly use the system and technical attributes ((Lin, 2007; Pham et al., 2019; Selim, 2007), their findings are mostly less significant on this attribute.

This research purpose several attributes on technical system quality to evaluate the quality of application mentioned above, namely: 1) Ease to access (Zeithaml, Parasuraman and Malhotra, 2002); 2) Ease to use (Zeithaml, Parasuraman and Malhotra, 2002; Yoo and Donthu, 2001); 3) Suitability of the feature and function (Parasuraman, Zeithaml and Malhotra, 2005); 4) Accessibility (Parasuraman, Zeithaml and Malhotra, 2005); 5) Ease to arrange the schedule; 6) Ease to invite; 7) Connectivity with other application; 8) Compatibility; 9) Ease of documentation; 10) Ease of entry; 11) Stability; 12) Low latency; 13) Personality security (Wolfinbarger and Gilly, 2003); 14) Attractiveness of background display (Barnes and Vidgen, 2002; Yoo and Donthu, 2001); 15) Login access; 16) Unlimited access.

\section{Perceived Satisfaction}

Satisfaction is the accumulation of consumer perceptions and behaviors derived from the total benefits obtained (WU, Tennyson and Hsia, 2010). Student satisfaction has gained much attention lately due to a rising competition among universities to attract and retain students (Leonnard and Susanti, 2019). That is of particular concern, especially in private universities. Private universities do not receive subsidized costs from the government and affect student 


\section{Leonnard}

admissions on higher education allowances and operational costs. Among many factors that have positive effects on students' satisfaction, service quality has been considered as the key factor (Leonnard et al., 2015; Leonnard and Susanti, 2019; Alemu and Cordier, 2017) as well as perceived value (Doña-Toledo, L., Luque-Martínez and Del Barrio-García, 2017; Leonnard, 2018a; b).

E-satisfaction is the level of consumer satisfaction with purchasing experience through online sites (Anderson and Srinivasan, 2003). Udo, Bagchi and Kirs, (2010) used the dimensions of the ability of online sites to provide satisfaction compared to the experience in previous online sites. The ability of online sites to provide services higher than consumer expectations, and pleasant experience provided. Nisar and Prabhakar, (2017) used similar dimensions of the ability of online sites to provide higher services and experience than consumer expectations and enjoyment to measure e-satisfaction. In terms of Higher Education Institution, Cheung and Lee, (2011) and Shaltoni et al., (2015) used the dimensions of the level of student satisfaction with information and systems to measure e-satisfaction of an e-learning portal.

Research conducted by Leonnard, (2018a) states that the way to evaluate satisfaction in education sectors may be different compared to other service sectors. If satisfaction is generally the result of a comprehensive evaluation after consumption of products and services (Fazlollahtabar and Muhammadzadeh, 2012; Gallarza, Gil-Saura and Holbrook, 2011 ) or emotional responses to the experience of interactions with an organization (Boulding et al., 1993), then educational institution satisfaction is obtained through the learning and teaching process and the process is intangible (Taylor, 1996).

In research related to e-learning, students are considered as customers of the services provided by educational institutions. To understand student satisfaction, educational institutions need to understand what attributes will then be factors that will determine the level of student satisfaction on e-learning. Some previous studies show that several factors might affect student satisfaction. For example, the quality of instructional service and noninstructional service is related significantly to perceived satisfaction (Martinez-Arguelles and Batalla-Busquets, 2008). In line with the study, course design, interaction with the instructor, and interaction with peer students are related to learning satisfaction (Goh et al., 2017). Likewise, the research is more specifically related to technical issues, where information quality, task-technology fit, system quality, utility value, and usefulness are related to elearning satisfaction (Al-Samarraie et al., 2017).

From a university customer's perception, there is a direct positive effect on perceived service quality on satisfaction (Leonnard, 2018a). In addition, student satisfaction in private 
universities mostly depends on the tangible factors quality and reliability including comfortable lecture rooms, sufficient library facilities, well-order look of staff, nondiscriminated service, and proper academic services provided by the university (Leonnard, 2018b).

Technical quality as mentioned by Al-Samarraie et al., (2017); Ali, Hossain and Ahmed, (2018); Masrom, Zainon and Rahiman, (2008) might have implications or effects on student satisfaction in e-learning. In this study, to evaluate the level of student satisfaction used several attributes, as follows: 1) General satisfaction of e-learning; 2) Satisfaction of the platform/portal/application; 3) Satisfaction of the lecturer; 4) Satisfaction of the IT support; 5) Satisfaction of the e-learning activities; 6) Re-utilization of the platform; 7) E-learning preference compared to face-to-face learning; 8) Comfortability of e-learning; 9) Further expectation of e-learning.

\section{Hypotheses}

Based on those literature reviews of relevant studies, it is predicted that preference of applications/platforms have a relationship to technical system quality and satisfaction of elearning. Various research used the technical approach for assessing the quality of elearning, such as Ali, Hossain and Ahmed, (2018) in Bangladesh, Masrom, Zainon and Rahiman, (2008) in Malaysia, and Peltier, Schibrowsky and Drago, (2007) in the US. Virtual teaching environments can be successful if having an appropriate technical environment (Basilaia and Kvavadze, 2020). Technical quality as mentioned by Al-Samarraie et al., (2017); Ali, Hossain and Ahmed, (2018); Masrom, Zainon and Rahiman, (2008) might have implications or effects on student satisfaction in e-learning.

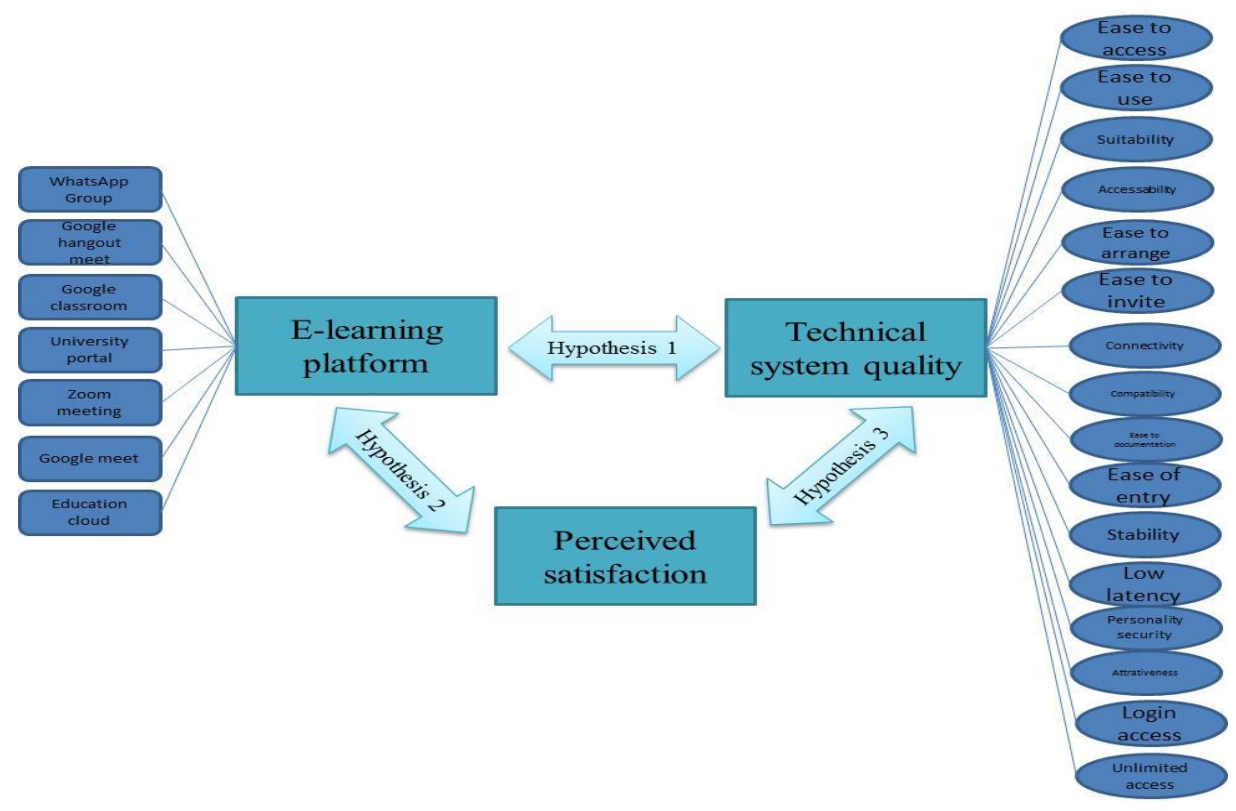

Figure 1.

Conceptual Framework 


\section{Hypothesis 1 : There is a significant relationship between e-learning plafform and technical system quality \\ Hypothesis 2 : There is a significant relationship between e-learning platform and perceived satisfaction}

Hypotehsis 3 : There is a significant relationship between technical system quality and perceived satisfaction

\section{RESEARCH METHODS}

The research aims to analyze the relationship between e-learning platforms, technical system quality, and perceived satisfaction of the students. The research surveyed 286 students of a university through a simple random sampling me

thod to examine the hypotheses. Because the population is homogeneous (campus residents), simple random sampling was used as the sampling method. Using this technique, the sample can be taken directly and represent every student of the campus population and have the same opportunity. All elements in the population are considered and each element has an equal chance of being chosen as the subject (Sekaran and Bougie, 2010). Because the population of students in the private university in Jakarta is around 1.000-1.100 students, based on Sekaran and Bougie, (2010), the sample size was 285. Thus, 286 students can represent the overall students of the campus.

The first step to calculate the data is to test the validity and reliability of the instruments. The pre-test was taken through the reciprocity of the students to obtain validity and reliability results. The measurements are obtained by using a 5-point Likert scale. Based on the questionnaire, 16 aspects/questions were asked to measure the technical quality, as mentioned in the attributes of technical system quality, namely: 1) Ease to access; 2) Ease to use; 3) Suitability of the feature and function; 4) Accessibility; 5) Ease to arrange the schedule; 6) Ease to invite; 7) Connectivity with other application; 8) Compatibility; 9) Ease of documentation; 10) Ease of entry; 11) Stability; 12) Low latency; 13) Personality security; 14) Attractiveness of background display; 15) Login access; 16) Unlimited access. Based on the validity test (corrected item-total correlation), only the r-value of question 15 (0.017 is below the r-table) was not valid, so that it was excluded from the next steps. Then, after excluding question 15 or login access, the reliability test was conducted, and ther-value (Cronbach's alpha 0.830 ) was more than r-table 0.553; thus, the variables are all reliable.

Meanwhile, the perceived satisfaction was measured through 9 questions/aspects, namely: 1) General satisfaction of e-learning; 2) Satisfaction of the platform/portal/application; 3) Satisfaction of the lecturer; 4) Satisfaction of the IT support; 5) Satisfaction of the e-learning 
activities; 6) Re-utilization of the platform; 7) E-learning preference compared to face-to-face learning; 8) Comfortability of e-learning; 9) Further expectation of e-learning. Based on the validity and reliability test, all aspects of perceived satisfaction are valid and reliable because the r-value was more than the r table.

Data analysis was performed using the SPSS software package. Since the independent and dependent factor data types were all categorical (nominal for platform data and ordinal for technical system quality and perceived satisfaction), a chi-square test was used to show the relationship between e-learning platforms and technical quality. and the satisfaction that students feel.

\section{RESULTS AND DISCUSSIONS}

Based on the questionnaire to 286 students, $25.5 \%$ percent of the sample was male, while $74,5 \%$ was female. The respondents included $95,8 \%$ of undergraduate students and $4,2 \%$ of master's degree students. Eventually, the population of students was dominated by the female gender and undergraduate program (entire university students of a private university in Jakarta). However, the gender or program intentions were not the purpose. Thus, unintentional gender and program level differences arise from the results of random sampling and are not expected to generate bias in the study.

The questionnaire also showed that there are different e-learning tools, techniques, or platforms used by the students. $54.9 \%$ of students used WhatsApp group application, while $19.2 \%$ and $13.6 \%$ used Google Hangouts Meet and Google Classroom applications respectively, Zoom meeting (9,8\%), university portal, Google Meet, and education cloud, each $0,7 \%$.

\section{Table 1.}

Chi-Square Tests of E-Learning and Technical System Quality Relationship

\begin{tabular}{lccc}
\hline & Value & Df & Asymp. Sig. (2-sided) \\
\hline Pearson Chi-Square & 10.801 a & 7 & .148 \\
Likelihood Ratio & 10.790 & 7 & .148 \\
Linear-by-Linear Association & .132 & 1 & .716 \\
N of Valid Cases & 286 & & \\
\hline a. 9 cells (56.3\%) have expected count less than 5. The minimum expected count is. 15. \\
Source: Calculated data
\end{tabular}

Those platforms preference was analyzed using cross-tabulation table to evaluate the relationship between platform preference and technical quality. Most respondents have perceived the high quality of any platform, except for education cloud platforms that had 
the same percentage between low and high perceived technical quality. Using the chisquare test as shown in Table 1, the results showed that there was no significant relationship between e-learning platform and technical system quality with a p-value of Pearson chisquare is $0.148(>0.05)$.

The second hypothesis is that there is a relationship between platform preference and perceived satisfaction. Using cross-tabulation table to evaluate the relationship between platform preference and perceived satisfaction. The overall percentage was almost the same between categories (54.2\% for low and $45.8 \%$ for high satisfaction level). Zoom meeting and education cloud were one had more high satisfaction level compared to other application/platform user groups, whereas Google Meet had the same percentage between low and high satisfaction level. Using the chi-square test table below, there is no significant relationship between e-learning platform and perceived satisfaction of the students ( $p$-value is 0.175 ).

Table 2.

Chi-Square Tests of E-Learning and Perceived Satisfaction Relationship

\begin{tabular}{|c|c|c|c|}
\hline & Value & Df & Asymp. Sig. (2-sided) \\
\hline Pearson Chi-Square & $10.241^{a}$ & 7 & .175 \\
\hline Likelihood Ratio & 12.150 & 7 & .096 \\
\hline Linear-by-Linear Association & 1.195 & 1 & .274 \\
\hline $\mathrm{N}$ of Valid Cases & 286 & & \\
\hline
\end{tabular}

a. 8 cells (50.0\%) have expected count less than 5 . The minimum expected count is .46 . Source: Calculated data

These tables showed that the platform choices do not affect students' perception of quality and satisfaction. Based on some previous literature, evaluation of technical system quality related to satisfaction is based on these quality attributes, including usability, quick responsiveness, time and cost-friendly Ali, Hossain and Ahmed, (2018), control of technology, interactive collaboration, design, access, and infrastructure (Selim, 2007). This finding indicates that the quality of e-learning is technically and student satisfaction does not depend on the brand platform as long as it can meet quality requirements. Especially during the Covid-19 pandemic, most of the use of these platforms was still quite simple (with the highest proportion still using Whatsapp groups, Google Hangout Meet, and Google Classroom.

Following these two comparisons, the study also analyzed the relationship between technical quality and perceived satisfaction. Using cross-tabulation table to evaluate the relationship between technical quality and perceived satisfaction. The overall percentage was almost the same between categories (54.2\% for low and $45.8 \%$ for high satisfaction level). In detail, a 
low level of technical quality contributed to a low level of perceived satisfaction. However, a high level of technical quality contributed almost the same between low and high satisfaction levels. Using the chi-square test table below, it was used the Fisher exact test value because the minimum expected count is $19.24>5$. Thus, there is a significant relationship between technical quality and the perceived satisfaction of the students ( $p$ value is 0.002 ).

Table 3.

Chi-Square Tests of Technical System Quality and Perceived Satisfaction Relationship

\begin{tabular}{lccccc}
\hline & Value & Df & $\begin{array}{c}\text { Asymp. Sig. } \\
\text { (2-sided) }\end{array}$ & $\begin{array}{c}\text { Exact Sig. (2- } \\
\text { sided) }\end{array}$ & $\begin{array}{c}\text { Exact Sig. (1- } \\
\text { sided) }\end{array}$ \\
\hline Pearson Chi-Square & $9.594 \mathrm{a}$ & 1 & .002 & & \\
$\begin{array}{l}\text { Continuity Correction } \\
\text { Likelihood Ratio }\end{array}$ & 8.583 & 1 & .003 & & \\
Fisher's Exact Test & 10.119 & 1 & .001 & .002 & .001 \\
$\begin{array}{l}\text { Linear-by-Linear } \\
\text { Association }\end{array}$ & 9.560 & 1 & .002 & & \\
N of Valid Cases & 286 & & & & \\
\hline
\end{tabular}

a. 0 cells $(0.0 \%)$ have expected count less than 5. The minimum expected count is 19.24.

b. Computed only for a $2 \times 2$ table

Source: Calculated data

Based on the results of the chi-square test where the technical system quality has a relationship with e-learning satisfaction in line with previous literature studies presented by AlSamarraie et al., 2017; Ali, Hossain and Ahmed, 2018; Masrom, Zainon and Rahiman, (2008). Therefore, given the condition of the Covid-19 pandemic which is currently still forcing educational institutions to implement distance learning, innovation in e-learning services needs to be developed continuously through any platform/application. E-learning innovations that are user friendly, cost-friendly, interactive, support adequate infrastructure Ali, Hossain and Ahmed, (2018); Selim, (2007) are an important concern for educational institutions to ensure the satisfaction of services provided to students or other relevant stakeholders who utilize the e-learning system. Besides, Quan, (2010); Sheng and Liu, (2010); Tandon, Kiran and Sah, (2017) confirmed that efficiency, fulfillment, system availability, and privacy have positive effects on e-satisfaction. Sheng and Liu, (2010); Ariff et al., (2013); Ting et al., (2016) also signified that fulfillment has a positive effect on e-satisfaction. Mohammed et al (2016) used information quality indicators that represented fulfillment and interactivity and reliability to represent system availability.

\section{CONCLUSION}

Based on these analyses, although the application/techniques/platforms of e-learning had no effect on the perceived technical quality and satisfaction of the students, e-learning technical quality of any form should be improved because it had a significant relationship to perceived satisfaction. Theoretically, the results of this study enrich the body of evidence that 


\section{Leonnard}

the brand of platforms/applications does not affect the perception of technical quality or user satisfaction, but rather the requirements or aspects of technical system quality that are closely related to user satisfaction, as delivered by Al-Samarraie et al., (2017); Ali, Hossain and Ahmed, (2018); Ariff et al., (2013); Masrom, Zainon and Rahiman, (2008); Mohammed et al., (2016); Quan, (2010); Sheng and Liu, (2010); Tandon, Kiran and Sah, (2017); Ting et al., (2016).

Meanwhile, practically, the findings of this study will force educational institutions to continue to innovate and improve the quality of the technical system of e-learning to increase the satisfaction of e-learning users, not only for students but also for instructors. Therefore, elearning quality should be improved in line with the innovation of a learning system during the pandemic. So that would increase students' satisfaction in the learning involvement. Many academic institutions that were earlier reluctant to innovate in e-learning, have to shift their paradigm from a traditional pedagogical approach, to gain their customersi.e their students.

Several top-rank universities in the United States in 2019 declared an e-learning emergency policy (Murphy, 2020). That was stated to protect the community $(84 \%)$, manage uncertainty (32\%), and threat response (8\%). A survey of universities in the United States also mentioned that $90 \%$ of educational institutions have used distance/virtual education to complete the teaching and learning process in the spring of 2020, as well as teachers (76\%) who report that they have changed teaching method becomes an online course to complete terms (Lederman, 2020). The survey also showed how instructors had changed their teaching methods towards students, $56 \%$ mentioned that they have used new teaching methods as a transition from traditional teaching systems to remote learning.

The research only focused on technical factors related to student satisfaction, mainly only on the types of platforms/applications used by students. Besides, the dimensions tested related to quality and satisfaction can be expanded considering that some previous studies have indeed more non-technical aspects that influence e-learning satisfaction. The perceived quality and satisfaction are not dependent only on technical quality perceived by students, but also on instructors, administrative staff, or other related stakeholders. This limitation may need further research to provide another view of instructors or other stakeholders.

Furthermore, e-learning is not only a challenge for the higher institution itself but also for the government to make sure that they provide relevant policy and infrastructure to support elearning technical system quality. The government also needs to ensure the quality of lecturers/instructors at higher education institutions, especially ensuring that this quality supports the concept of a Free Learning on Free Campus (Merdeka Belajar Kampus Merdeka). 


\section{REFERENCES}

Al-Samarraie, H., Teng, K.B., Alzahrani, I.A. and Alalwan, N. 2017. E-learning continuance satisfaction in higher education: A unified perpective from instructors. Studies in Higher Education, 8(March): 1-17.

Alemu, A.M. and Cordier, J. 2017. Factors influencing international student satisfaction in Korean universities. International Journal of Educational Development, 57: .54-64.

Ali, M., Hossain, S.M.. and Ahmed, T. 2018. Effectiveness of Elearning for university students: evidence from Bangladesh. Asian Journal of Empirical Research, 8(10): 352-360.

Anderson, R.E. and Srinivasan, S.S. 2003. E-satisfaction and e-loyalty: A contingency framework. Psychology \& marketing, 20(2): 123-138.

Ariff, M.S.M., Yun, L.O., Zakuan, N. and Ismail, K. 2013. The impacts of service quality and customer satisfaction on customer loyalty in internet banking. Procedia-Social and Behavioral Sciences, 81: 469-473.

Barnes, S.J. and Vidgen, R.T. 2002. An integrative approach to the assessment of ecommerce quality. J. Electron. Commerce Res., 3(3): 114-127.

Basilaia, G. and Kvavadze, D. 2020. Transition to Online Education in Schools during a SARSCov-2 Coronavirus (COVID-19) Pandemic in Georgia. Pedagogical Research, 5(4).

Boulding, W., A, K., R, S. and VA, Z. 1993. A dynamic process model of service quality: From expectation to behavioral intentions. Journal of marketing research, 30: 7-27.

Bressolles, G. and Nantel, J. 2008. The measurement of electronic service quality: Improvements and application. International Journal of E-Business Research (IJEBR), 4(3): 1-19.

Chen, Y.H. 2011 . Undergraduates' perceptions and use of the university libraries Web portal: Can information literacy instruction make a difference? Proceedings of the American Society for Information Science and Technology, 48(1): 1-10.

Cheung, C.M. and Lee, M.K. 2011. Antecedents and consequences of user satisfaction with an e-learning portal. International Journal of Digital Society, 2(1): 373-380.

Cojocariu V.-M., Lazar I., Nedeff V., L.G. 2014. SWOT analysis of e-learning educational services from the perspective of their beneficiaries. Procedia-Social and Behavioral Sciences, [online] 116: 1999-2003.

Dhawan, S. 2020. Online Learning: A Panacea in the Time of Covid-19 Crisis. Journal of Educational Technology Systems: 1-18.

Ding, D.X., Hu, P.J.H. and Sheng, O.R.L. 2011. e-SELFQUAL: A scale for measuring online selfservice quality. Journal of Business Research, 64(5): 508-515.

Doña-Toledo, L., Luque-Martínez, T. and Del Barrio-García, S. 2017. Antecedents and consequences of university perceived value, according to graduates: The moderating role of Higher Education involvement. International Review on Public and Nonprofit Marketing, 14(4): 535-565. 


\section{Leonnard}

Fazlollahtabar, H. and Muhammadzadeh, A. 2012. A knowledge-based user interface to optimize curriculum utility in an e-learning system. International Journal of Enterprise Information Systems, 8(3): 34-53.

Gallarza, M., Gil-Saura, I. and Holbrook, M. 2011. The value of value: Further excursions on the meadning and role of customer value. Journal of consumer behaviour, 10(4): 179-191.

Goh, C., C, L., P, K.K.H. and O, T. 2017. Students' experiences, learning ourcomes, and satisfaction in e-learning. Journal of e-earning and knowledge society, 13: 117-128.

Google, 2020a. Manage Teaching and with Classroom. [online] Available at: <https://edu.google.com/intl/id/products/classroom/?modal_active=none>.

Google, 2020b. Premiun video meeting: Now free for everyone. [online] Available at: <https://apps.google.com/meet/>.

Grönroos, C., 1984. A service quality model and its marketing implications. European Journal of marketing, 18(4): 36-44.

Kaisara, G. and Pather, S., 2011. The e-Government evaluation challenge: A South African Batho Pele-aligned service quality approach. Government information quarterly, 28(2): $211-221$.

Karunasena, K. and Deng, H. 2012. Critical factors for evaluating the public value of egovernment in Sri Lanka. Government Information Quarterly, 29 (1): 76-84.

Lederman, D. 2020. How teaching changed in the (forced) shift to remote learning. Inside Higher Ed.

Lee, H.S., Choi, Y.H. and Jo, N.O. 2009. Determinants affecting user satisfaction with campus portal services in Korea. Journal of Internet Banking and Commerce, 14(1): 1-18.

Leonnard, 2018a. Perceived Service Quality, Perceived Value for Money, Satisfaction and Repurchase Intention: An Evaluation on Private Univerisity Services. International Journal of Commerce and Finance, 4(1): 40-51.

Leonnard, 2018b. Performance of SERVQUAL to Measure Service Quality in Private University. Journal on Effciency and Responsibility in Education and Science, 11(1): 16-21.

Leonnard, L., Daryanto, H.K., Sukandar, D. and Yusuf, E.Z. 2015. The Loyalty Model of Private University Student. International Research Journal of Business Studies, 7(1).

Leonnard and Susanti, Y.F. 2019. The Advocacy Model of Indonesian Chinese Students, the Affluent Market. International Journal of Instruction, 12(1).

Lin, F. 2007. Measuring online learning systems success: Applying the updated DeLone and McLean model. Cyberpsychology \& Behavior, 10(6): 817-820.

Martinez-Arguelles, J.M., Callejo, B.M. and Farrero, M.C.J. 2013. Dimensions of perceived service quality in higher education virtual learning environments. Universities and Knowledge Society Journal, 10(1): 268-285. 
Martinez-Arguelles, M. and Batalla-Busquets, J. 2008. Perceived service quality and student loyalty in an online university. International Review of Research in Open and Distributed Learning, 17(4).

Masrom, M., Zainon, O. and Rahiman, R. 2008. Critical success in e-learning: An examination of technological and institutional support factors.

Mohammed, M.E., Wafik, G.M., Jalil, S.G.A. and El Hassan, Y.A. 2016. The Effects of E-Service Quality Dimensions on Tourist's e-Satisfaction. International Journal of Hospitality \& Tourism Systems, 9(1): 12-20.

Murphy, M. 2020. COVID-19 and emergency elearning: Consequences of securitization of higher education for post-pandemic pedagogy. Contemporary Security Policy, 4(3): 492-505.

Nisar, T.M. and Prabhakar, G. 2017. What factors determine e-satisfaction and consumer spending in e-commerce retailing? Journal of retailing and consumer services, 39: 135144.

Parasuraman, A., Zeithaml, V.A. and Malhotra, A. 2005. ES-QUAL: a multiple-item scale for assessing electronic service quality. Journal of service research, 7(3): 213-233.

Peltier, W.J., Schibrowsky, A.J. and Drago, W. 2007. The interdependence of the factors influencing the perceived quality of the online learning experience: A causal model. Journal of Marketing Education, 29(2): 140-153.

Pham, L., B, Y., Limbu, Bui, T.K., Nguyen, H.T. and Pham, H.T. 2019. Does e-learning service quality influence e-learning student satisfaction and loyalty? Evidence from Vietnam. International Journal of Educational Technology in Higher Education, 16(7).

Quan, S. 2010. Assessing the effects of e-service quality and e-satisfaction on internet banking loyalty in China. International Conference on E-Business and E-Government: 93-96.

Rotchanakitumnuai, S. 2008. Measuring e-government service value with the E-GOVSQUALRISK model. Business Process Management Journal, 14(5): 724-737.

Rust, R. and Oliver, R. 1993. Service quality: New directions in theory and practice. Sage Publications.

Salesforce, 2020. [online] Available at: <https://www.salesforce.org/highered/>.

Sekaran, U. and Bougie, R., 2010. Research Methods for Business: A Skill Building Approach. John Wiley \& Sons Ltd.

Selim, H.M., 2007. Critical success factors for e-learning acceptance: Confirmatory factor models. Computers \& Education, 49(2): 396-413.

Shaik, N., Lowe, S. and Pinegar, K. 2006. DL-sQUAL: A multiple-item scale for measuring service quality of online distance learning programs. Online Journal of Distance Learning Administration, 9(2): 201-214.

Shaltoni, A.M., Khraim, H., Abuhamad, A. and Amer, M. 2015. Exploring students' satisfaction 


\section{Leonnard}

with universities' portals in developing countries: A cultural perspective. The International Journal of Information and Learning Technology, 32(2): 82-93.

Sheng, T. and Liu, C. 2010. An empirical study on the effect of e-service quality on online customer satisfaction and loyalty. Nankai business review international, 1 (3): 273-283.

Tandon, U., Kiran, R. and Sah, A. 2017. Analyzing customer satisfaction: users perspective towards online shopping. Nankai Business Review International, 8(3): 266-288.

Taylor, S. 1996. Consumer satisfaction with marketing education: Extending services theory to academic practice. Journal of consumer satisfaction dissatisfaction and complaining behavior, 9: 207-220.

Tella, A. and Bashorun, M.T. 2012. Undergraduate students'satisfaction with the use of web portals. International Journal of Web Portals (IJWP), 4(2): 56-73.

Ting, O.S., Ariff, M.S.M., Zakuan, N., Sulaiman, Z. and Saman, M.Z.M. 2016. E-Service Quality, ESatisfaction and E-Loyalty of Online Shoppers in Business to Consumer Market; Evidence form Malaysia. In IOP Conference Series: Materials Science and Engineering, 131 (1).

Udo, G.J., Bagchi, K.K. and Kirs, P.J. 2010. An assessment of customers'e-service quality perception, satisfaction and intention. International Journal of Information Management, 30(6): 481-492.

Valverde-Berrocoso, J., C, G.-A.M., C, B.-V. and B, M.-C.M. 2020. Trends in Educational Research about e-Learning: A systematic Literature Review (2009-2018). Sustainability, 12(5153).

Verma, G., T, C., W, M. and B, P. 2020. Science Teacher Education in the Times of the COVID19 Pandemic. Journal of Science Teacher Education, 31 (5): 483-490.

Wang, S.Y., Wang, Y.H. and Shee, Y.D. 2007. Measuring e-learning systems success in an organizational context: Scale development and validation. Computers in Human Behavior, 23: 1792-1808.

WhatsApp, 2020. [online] Available at: <https://www.whatsapp.com/features/>.

Wolfinbarger, M. and Gilly, M.C. 2003. eTailQ: dimensionalizing, measuring and predicting etail quality. Journal of retailing, 79(3): 183-198.

Wu, J.H., Tennyson, R.D. and Hsia, T.L. 2010. A study of student satisfaction in a blended elearning system environment. Computers \& Education, 55(1): 155-164.

Yoo, B. and Donthu, N. 2001. Developing a scale to measure the perceived quality of an Internet shopping site (SITEQUAL). Quarterly journal of electronic commerce, 2(1): 3145.

Zeithaml, V. 1988. Consumer perceptions of price, quality, and value: a means-end model and synthesis of evidence. The Journal of marketing: 2-22.

Zeithaml, V.A., Parasuraman, A. and Malhotra, A. 2002. Service quality delivery through web sites: a critical review of extant knowledge. Journal of the academy of marketing science, 30(4): 362-375. 
Zhang, Y.L. and Bi, R.F. 2017. Studying on enhancing readers' satisfaction model of electronic service quality in library based on LibQUAL+ and Kano. Procedia engineering, 174: 260266.

Zoom, V.C. 2020. Zoom meetings \& Chats. [online] Available at: <https://zoom.us/meetings>. 